\author{
IRYNA BERMES \\ Drohobych Ivan Franko State Pedagogical University \\ ORCID: https://orcid.org/0000-0001-5752-9878
}

\title{
VALUE BASICS OF MUSICAL ENLIGHTENMENT (ON THE EXAMPLE OF EASTERN GALICIA IN THE FIRST HALF OF THE $20^{\mathrm{TH}}$ CENTURY)
}

\begin{abstract}
The origins of musical education are rooted in the knowledge of beneficial influence of music on the human soul and its significant educational effect. Musical education can be regarded as an activity that ensures the development of musical interests, needs and tastes, and generally promotes the formation of the foundations of music.

Education based on musical information is important for the individual musical development, for raising of one's cultural level. Educational idea mostly comes down to ensuring wide access to genuine musical values. As an activity, music education is closely linked with issues of training and schooling. Its main task is to involve different social groups into musical life, introducing them to the various musical sources - folk songs, examples of national and world musical heritage, sharing knowledge about music. Since music is correlated with artistic images, appealing to the feelings of people, it can contribute to their spiritual purification. Specificity of musical education is in organizing prolonged and frequent contacts of listeners with music, in a voluntary initiative of performers and listeners in the quest for self education. One of the main "consumers" of musical information, the target of musical education is a listener.

An important factor in the cultural development of Ukrainian East Galicia in the first third of the $20^{\text {th }}$ century were the ensembles connected with community organizations such as "Prosvita", "Bojan", "Ridna Shkola", "Plast", "Sich" and others. Their participants were amateurs, the most active forces of the area that supported the traditions of Ukrainian national identity and cultural progress. Musical educational movement concentrated in choirs, orchestras, theater circles at various community organizations, each of which occupies a niche in the cultural space of Eastern Galicia.
\end{abstract}

Keywords: education, music education, concert, self education, Eastern Galicia

Musical enlightenment is a kind of syncretic activity, an important part of students' cultural development and not only. Moreover, it is an inseparable part of a music teacher's job. 
Noticeable changes are taking place in modern Ukrainian society. They concern all spheres of life, including education, the values of which correlate with the system of a person's and the community's life values for several reasons. Firstly, education satisfying human's needs for the cognition of the world and himself, creates an essential prerequisite considered to be one of the most crucial life values. Secondly, performing its socially caused functions to train new generations for life and social activity, education comprising a whole set of knowledge, habits and skills, includes the upbringing component the purpose of which is to satisfy a personality's moral and ethical needs and cherish his life value and ideals typical of the given society.

Changes in a person's value orientations demand reinterpretation of the role of education in social life, its transformation into an important factor of national culture and spirituality revival, enriching the people's intellectual potential. Undoubtedly, life will make some changes in the system of education. Nevertheless, its modern model should not lose its historical achievements that are based on national traditions and hence remain significant and vital for the pedagogical practice of today. Musical enlightenment is not an exception. It should become its important constituent.

An integral precondition for the development of education and culture of an independent Ukrainian state is conducting a study and reconsideration of the historical experience of our people, preserving, and using its culture-creating potential. The subject of the discussion, first and foremost, covers those periods of Ukrainian history which were characterised by rebirth and restoration of national consciousness, shaping of new patterns of reception of the world, reconstruction of the manner of thinking. One crucial period for understanding this is the last quarter of the $19^{\text {th }}$ century in East Galicia which was the age of nation-building, national self-identification of Ukrainians, age of musical enlightenment that unfolded full throttle in the first quarter of the $20^{\text {th }}$ century prior to the Second World War.

The history of cultural development, from the olden days into the present time, is related to the enlightenment as a social and cultural phenomenon which is necessarily characterised not only by acquisition of new knowledge but also by their transfer. The drive for enlightenment is something that provides a momentum to a human being, not letting people stop and rest at what they have already achieved but prompting them to proceed with creative quest, self-improvement, self-education.

Enlightenment also includes treating problems to which we are accustomed as eternal ones since each subsequent era reveals new prospects in the dissemination of education and popularisation of knowledge in the society at large. Throughout 
many centuries, it has been one of the prime factors in human development. Since the olden days, the role played by the enlightenment in the spiritual accomplishment of a personality has been an object for deliberations by philosophers who linked it to the upbringing of a personality as it gains social and cultural experience necessary to lead a fully functional life in society.

\section{ENLIGHTENMENT AND MUSICAL ENLIGHTENMENT IN SCIENTIFIC REFLECTIONS}

Issues of enlightenment which included musical enlightenment were covered by foreign academics such as B. Asafiev, M. Bialyk, Z. Hladkykh, N. Hrodzenska, M. Kosmovska, Ye. Lehostaiev, V. Medushevskyi, L. Melnykova, N. Savelieva, V. Shatska, B. Yavorskyi, and others. Foundations for enlightenment activities in culture and education have also been explored by Ukrainian scholars in their dissertations and other works in various periods of time; these included academics such as L. Berezivska, P. Bilichenko, R. Harat, M. Danyliuk, L. Kyianovska, N. Kobryn, T. Kolomiiets, Ya. Lysenko, O. Melnyk, Z. Nahachevska, V. Naida, H. Padalka, N. Fradkina, O. Tsapko and others. The broader context of musical enlightenment has, however, never been an object of special attention as it has effectively fallen out of the focus of scientific quests. Thus, the goal of the present article is to reveal the nature of musical enlightenment as a cultural and historical phenomenon (using East Galicia in the $20^{\text {th }}$ century before the Second World War as an example).

$\mathrm{V}$. Dal has presented enlightenment as "light of science and intelligence provided with warmth of pure morality; development of mental and moral forces of a person"; clear realisation of "one's duty and purpose in life" (Dal 2000, p. 541).

In S. Ozhehov's dictionary, the term "enlightenment" is defined as "dissemination of knowledge and education" (Ozhehov 1985, p. 537). To "enlighten" or "inform" means "to provide knowledge (...), to disseminate achievements of culture" (ibid.) in order to make the human being more educated.

E. Pomelova characterises enlightenment as "a committed fruitful activity pursued by a person or a group of persons engaged in the development of education in difficult social conditions" (Pomelova 2005, p. 11).

In the contemporary language studies, the term "enlightenment" is often perceived to be a synonym for the word "education" whereby it stands for "the process of acquisition and comprehension of knowledge; studying" (Kuznetsov 2001, p. 641). A more narrow understanding of the term defines it as "the main purpose of a musical circle (...)" (Selytskyi 2012, p. 342); a broader definition stipulates it as "dissemination of knowledge, education, culture" (Kuznetsov 2001, p. 641). 
The root of the word "enlightenment" in the Ukrainian language is the word "world" (svit) which is central to the understanding of its sense. Somewhat related meanings from the lexical and semantic standpoint may be noticed in many other European languages as well. The English "enlightenment" has "light" as its root; the German Aufklärung ("clearing out") has klar ("clear", "defined", "light", "precise", "understandable"); the French use the term Siècle des Lumières ("age of illuminators", "age of provision of light") derived from lumière ("light", "fire").

Enlightenment is a multifaceted phenomenon. It is mostly understood as the pan-European cultural and ideological movement of the late $17^{\text {th }}$-early $18^{\text {th }}$ centuries preoccupied with a task to "break down" the conservative forms of social, cultural, and spiritual life. Dissemination of avant-garde ideas and knowledge in an environment unable to gain access to sources of information is the prime task of the cause of enlightenment. The peak of progressive social activity in this sense was the era of Enlightenment in France whereby names of Voltaire, J.-J. Rousseau, J.G. Herder, F. Schiller, J.W. von Goethe, and other encyclopaedic thinkers have been revealed to the world. In the $18^{\text {th }}$ century, the term "enlightenment" was used by Voltaire, Herder and ultimately E. Kant who defined its mainstream topic in the work entitled Answering the Question: What Is Enlightenment? (1784). As per Kant, Enlightenment is free usage of human mind for progressive transformation of society - "freedom to use one's mind and all of the elements thereof" (Rudnitsky, Feshovets 2003, p. 159).

Enlightenment is not only education provided nationwide to all social strata with their intellectual potential being enhanced and increased; it is also a way of getting closer to the values of culture and art as a whole.

In order for the society not to lose one's spiritual landmarks within a certain period of history, a matter of crucial importance is enlightenment-targeted activity which is to gain forms in accordance with the tasks stipulated by the cultural, social, and economic requirements. The enlightenment activity is an important foundation for building up a personality possessing a clear and definite position and a firmly composed system of values. Moreover, the ideas of common good, beauty, and kindness that are motives of the enlightenment are related to the recognition of the life of every human on earth as a thing of paramount value as the human should be able to implement his or her creative potential in his or her creative activity. As per V. Hubiak, the "enlightenment activity" is a system of "organisational, educational, artistic, and mass communication (such as periodicals, printed press, and book publishing business) measures taken by Ukrainian civil society organisations ("Prosvita", "Ridna Shkola", "Luh", "Sich", "Plast", "Silskyi Hospodar", "Soiuz Ukrainok" and others) that are aimed at giving shape to the national and cultural space, civil society, and upbringing of an educated 
and nationally aware Ukrainian citizen" (Hubiak 2004, p. 3). The cultural and enlightenment activity is focused upon the human, particularly upon the enrichment of the human's "spiritual world" (as per O. Vasilieva, this term stands for "the cumulative achievements of activities pursued by human as an active entity striving to satisfy his/her internal natural needs"; it is a microcosm and an inseparable unity of mind, feelings, and will - I.B.), and culture (as per E. Taylor, culture stands for "knowledge, beliefs, morality, right, laws, customs, skills, and abilities acquired by humans as members of a society"; as per O. Shokalo, it is "a system of self-development, self-actualisation of a human and his or her spiritual self-creation"). Thus, the value of enlightenment in the development of a human as a creature of thinking and education, as a creature that is tolerant, open, and ready to communicate can hardly ever be exaggerated.

Scientists are utilising terms such as "musical enlightening" and "musical enlightenment" that should be separated. The musical enlightenment is understood by N. Saveleva as "the process of dissemination of phenomena of musical culture in the society" (Saveleva 2013, p. 83) which unites all kinds of musical activity: composing, performing, musicology, musical pedagogy, and concert-craft as well as forms adjacent to them that have emerged throughout history: the composing and performing practice, musical critique, pedagogical and concert organisations.

We should highlight right from the onset that musical and enlightenment activity is viewed in various dimensions: "as a means of artistic communication with the audience (M. Kahan), as a basis for the lectorial practice of a musicologist (Ye. Dukov), as a tool for development of oratorical skills (Ye. Nozhyn, N. Babych)" (Melnyk 2009, p. 9), whereas musical enlightenment is "a part of musical enlightening manifested in the form of its own methods and forms related to preparation, organisation, and implementation of musical programmes" (Saveleva 2013, p. 8).

The essence and content of the notion of "musical enlightenment" is related to creation of culture which, according to O. Zhornova, is a phenomenon "existing in the inseparability of the individual and the society"; the activity "related to the emergence of new, non-risky, socially significant cultural meanings, senses, or artefacts" (Zhornova 2012). One variety of cultural creativity is the musical activity which, in the enlightenment movement, is in fact the comprehension of musical knowledge and skills and relaying this knowledge via creative work and performances by teams from musical, educational, or public institutions. By referring to O. Apraksina, the essence of musical enlightenment is expressed in the "common musical awareness, listening to music and understanding it" (Apraksina 1956, p. 98). Roots of musical enlightenment are in the realisation of the beneficial impact that the music has on the soul of the person and realisation of the music's significant power as a tool of education. Musical enlightenment may be positioned 
as activity ensuring the development of musical interests, needs, and tastes and in general it contributes to building up the basis of musical culture.

\section{THE ESSENCE OF MUSICAL ENLIGHTENMENT IN THE GALICIAN ENVIRONMENT OF THE 1920s-1930s}

Enlightenment based on musical information plays an important role in the "musicalisation" of personality and elevates the personality's level of culture. The idea of enlightenment is largely reduced to the ensuring of wide access to real musical values. As a form of activity, musical enlightenment is closely related to matters of education and upbringing. Its prime task is to engage the representatives of various social groups in musical life, bringing them closer to miscellaneous sources of music such as folk songs, specimens of domestic and worldwide musical heritage, procurement and dissemination of knowledge about music.

Since music correlates with artistic images, appeals to feelings of people, it can contribute to their spiritual purification. Moreover, music is the actual integrating correlative that is able to unite like-minded associates around it. The specifics of musical enlightenment consists in the activities initiated by the performers and the audience, in the long-lasting and frequent contacts of listeners with music, in their striving for self-education. The main actors of enlightenment are the performers, whereas the consumers of musical information and the immediate object of it are the audience.

Musical and enlightenment activity is a necessary and socially significant thing. Participants of the enlightenment movement should be in possession of a set of psychological, pedagogical, and specialised knowledge, skills, and abilities; they should manifest commitment to sacrifice their efforts to the benefit of the mission of enlightenment. The most efficient way to actualise musical enlightenment is through studying and popularisation of specimens of national and global musical culture for the broader audience.

Musical enlightenment manifests itself in the most vivid form in the organisation of concerts, provision of support to systematic contacts between the audience on the one hand, and the musical artefacts on the other hand. It is largely represented by such spectacular forms as a concert (be it topical, author's, collective, taking place in the form of a theatrical performance or on the occasion of a jubilee), a musical academy, vechornytsi, a concert lecture, presentation concerts prepared by artistic bands, a theatrical play or any other form. A concert is a form of audio communication, in the musical artefacts of which the sound as an acoustic signal is an important carrier of information embedded into it. The response to the 
sound, the perception of musical information are important functions enriching the general and musical experience, impacting the emotional condition of the audience, setting them at the "frequency" of positive contact with the performers, the surrounding world, and the spiritual areas of personality through getting familiar with the musical works and elaboration of moral, ethical, and aesthetic landmarks.

One crucially important thing in the musical enlightenment is the repertoire. The concert repertoire has been acquiring a certain shape in accordance with the way in which the society has been perceiving certain specimens of artistic heritage created by individual composers and/or by the people, "the folk". The term "repertoire", according to N. Saveleva, is understood as "a part of phenomenal line represented by creative works of composers who are possessing the force of enlightenment influence on the audience environment" (Saveleva 2013, p. 14). It is to comply with the content of enlightenment; it should be a concentration of the set of artistic specifics required for this stage of social development. The audience (which is the auditorial space, according to Saveleva) not only receives and perceives musical information in the course of the concert but also boosts the musical conscience. According to O. Samoilenko,

(...) musical conscience is (...) the central component of the conscience of culture understood as memory since, as a result of the music's special capacity to implement extraverbal senses, (...) it is directly related to the perceptive thesaurus of culture and, by replicating it, by "recalling" it, is incessantly supplementing it and transforming it (Samoilenko 2009, p. 68).

The opulent palette of repertoires and genres in concert programmes correlates with the notion of a "concert situation" (as per A. Ahmedhodzhaieva) which bears a range of features of which we should stress the current necessity of and current demand for a specific work; the ability of performers to pursue public activity; the readiness of the public to accept musical works.

By stipulating the phenomenon of musical enlightenment as a form of creative and performing activity aimed at acquisition of musical knowledge, skills, abilities, and enhancement of musical competence of a human through active practising of music (participation in amateur bands), popularisation of samples of Ukrainian and Western European music, and perceiving their content, the author states that musical enlightenment is one of the productive traditions of Ukrainian culture.

Enlightenment activity is a phenomenon peculiar to Ukrainian culture in the Galician environment in the last quarter of the $19^{\text {th }}$ century and in the early $20^{\text {th }}$ century prior to the Second World War. Within the defined period of time, it had 
a colossal influence upon the formation of its aesthetic Weltanschauung, first and foremost upon the growth of national self-awareness.

Emergence and establishment of musical enlightenment in the Galician milieu of the aforementioned period of history can, of course, be explained. Firstly, the subjugated status of Ukrainianness in East Galicia urged its adherents to foster an autochthonous culture that was compliant with the individual psychological type of an introvert Galician. The self-centred, self-immersed, perceptive, and aesthetic nature of a Galician was implemented in the space of enlightenment in the broadest possible fashion. Secondly, the practice of concerts as one of the forms of musical enlightenment of the time was being implemented by amateurs that had been fervently preserving popular traditions and customs - first of all the tradition of a collective singing - that had been embedded genetically and historically. Concert activity was also supported by professional musicians that were academic teachers at musical training institutions (such as the Higher Musical Institute and its affiliates) or that had been visiting when on tour; by non-governmental associations that were founding choirs, orchestras, theatrical groups, organising public concerts; by patrons that were supporting the initiatives in various material ways, by contributing to the elevation of the cultural level of Ukrainians and by supporting the continuity of the enlightenment process.

Although by the end of the $19^{\text {th }}$ century and way up until the Second World War, management (understood as a way of communication with people and the art of directing activities - I.B.) of concert activities of amateur bands was not something that was clearly outlined, it certainly did exist de facto and per se. Any concert project inevitably featured such constructive elements as an artistic idea, composition and preparation of a programme, composition and organisation of a concert, provision of a concert area, funding, implementation of an idea behind a certain undertaking, etc. These tasks were successfully accomplished by managements of cultural, education, and public associations.

Performance practice of amateur bands of cultural and enlightenment associations was based upon organisation of vocal, choral, instrumental, and symphonic concerts as an artistic phenomenon being a composition of a range of works unified by a common idea and plot. Concerts were tools enabling to disseminate musical artefacts - first of all the Ukrainian ones - across society: they facilitated the revelation of their content, formed moral and aesthetic landmarks for the society, its "musical awareness" (as per B. Yavorskyi and T. Adorno). Viewed as forms of musical enlightenment, they were characterised by multitude of options, by miscellany as far as genres were concerned, by unification of various kinds of arts (music, poetry, choreography) in a topical concert. They can be viewed as projects aimed at provision of certain services. Dramatic art of topical programmes was 
closely related to the verbal content. The enlighteners tried to practically introduce the available musical works which would be overcoming the intellectual, temporal barrier in the process of perception; which would initiate the application of verbal explanations to the programmes in the form of excerpts/summaries (both spoken and written ones such as posters, announcements, programmes, leaflets).

Conducting theatre-like concerts (in the opinion of M. Melnyk, expressive means of theatrical manifestation include "a symbol, a metaphor, an allegory that are used to create the unique and spectacular concert performance whereby an important unit of scenic information is the sequence number" (Melnyk 2009, p. 17)), preceding the programme with an introduction speech - all of the above assists the audience in gaining a better and deeper understanding of the composer's idea and sometimes also his/her era and style (in general), artistic image and suchlike. Concerts of this kind were both informative and exerted a spiritual and moral influence upon the audience and provided an aesthetic satisfaction at the same time.

The concert activity pursued by amateur associations has, in a certain manner, correlated with the psychological, sociological, aesthetic demands of both performers and the audience. Its social characteristics were shaped, first and foremost, by the spiritual needs of the people, by the level of people's education, by the emergence of leaders possessing a sufficient degree of musical intelligence, social activity, and who were - correspondingly - influencing the enlightenment processes. They, as a rule, were managers/directors of the performing musical bands/teams/groups regardless of the fact that they were not professionals in this business.

One important factor of cultural renaissance of Ukrainians in East Galicia in the early $20^{\text {th }}$ century were the artistic bands that were operating alongside cultural and enlightenment associations. Their participants were amateurs, the most vigorous forces of the land that were supporting the "traditions of Ukrainian national uniqueness and cultural progress" (Semchyshyn 1993, p. 518). The musical and enlightenment movement was centred around choirs, orchestras, theatrical teams by various associations, each of which was occupying its niche in the cultural environment (amateur bands of the "Prosvita" as well as those belonging to the paramilitary organisations such as "Sich", "Sokil", "Plast"; specialised musical organisations such as "Boian" featuring a musical school, a library, a music sheet publishing house, etc.). Their concert activities were characterised by high level of artistry and organisation, both crucial to fostering good taste among the audience.

Thanks to the activities organised by the governing boards of these associations, social interest in musical events has grown substantially as far as ideas for celebration of commemorative dates and other noteworthy events were concerned. Such concerts were taking place to glorify the artistic achievements of prominent 
Ukrainian cultural figures (men of letters, composers and others) as well as honourable guests visiting Galicia. Shevchenkian and Lysenkian academies, concerts commemorating Franko, Shashkevych, Lesia Ukraiinka, religious and secular musical events have noticeably invigorated Ukrainian national movement; these were attended by the best performing bands.

The national enlightenment's "seme code" (as per Roland Barthes), its national concept became Taras Shevchenko; concerts dedicated to him were awakening for the national consciousness, fortified the uniqueness of Ukrainians, confronted their denationalisation. Mikhnovskyi stressed that "there is one day - the feast of our great poet - when all of these Ruthenians, Little Russians, Khokhols, Cherkassians, Rusyns, Rusnaks... all of them feel that they are children of one mother - Ukraine (...) they are perceiving themselves as equals with other nations and a common heartbeat of all Ukrainians resounds all around" (Promova..., 1909, p. 4).

Musical enlightenment became an important part of Ukrainian school's activity. School drama and choral circles play an important role. I. Yushyshyn singles out their purpose and tasks in the journal "The Way of Teaching and Rearing":

(...) 6. Drama circles should arouse the school youth's love for the Arts, beauty in general, and especially for the stage and drama works. To perform their tasks, drama circles: a) study stage works; b) do stage exercises; c) give the performances on various occasions such as the end of a school year, New Year, different school and national holidays, etc; d) make stage costumes and decorations. 7. Vocal groups aim at making the school youth like the Arts, especially singing and music and the beauty in general. To perform their tasks, vocal groups: a) study the notes thoroughly under the teachers' supervision; b) develop and correct their voices under the teachers' supervision; c) learn folk songs and melodies; d) give song parties and the concerts on special occasions (...) (Yushyshyn 1927, pp. 3-4).

Another important component of musical enlightenment was music listening in which student bands participated. V. Yagell state lyceum and grammar school directorate's report for the 1938-1939 school year runs:

(...) a) Choral singing: the choir consists of 45 students. It took part in 6 school celebrations. 22 secular and spiritual songs learnt -2 of them for 2 voices, 20 songs for 3 and 4 voices (...); b) Playing the violin - 1 hour per day; attendance - 16 students; rehearsal - twice a week; the number of violinists -8 . The ensemble participated in musical auditions. The repertoire comprised 18 musical works arranged for 3 violins; c) Musical auditions: 5 of them. Each audition consists of 2 parts: 1) theoretical; 2) practical. 1) The theme of Audition One: Symphony. 2) The theme of Audition Two: 
Franz Schubert. 3) The theme of Audition Three: Frédéric Chopin. 4) The theme of Audition Four: Wolfgang Amadeus Mozart. 5) The theme of Audition Five: Ludwig van Beethoven (Zvit dyrektsii..., 1939, p. 190).

It is worth mentioning that such auditions were arranged for students of other city schools. Concert and educational activity of the circles mentioned above as one of the important tendencies of musical enlightenment and its varieties was based on the cooperation between the subjects of artistic and creative process: a teacher training the ensemble and annotating the programme on one side, the performers and the audience on the other one.

In the $20^{\text {th }}$ century, concert life, as an important factor of musical enlightenment, became a stable tradition for the cause of representing Ukrainianness in the condition of foreign domination, a phenomenon common to the Galician reality, and, at the same time, a powerful impulse urging them to self-actualise and become united. Centres of reflection of brand new directions of development of the musical life were still choirs and orchestras which "laid foundation for the upcoming golden age of musical art in the land" (Kyianovska 2000, p. 98) and for professionalisation of the musical life.

The main landmark for cultural and art practised by the enlightenment societies and school concert groups in the Ukrainian space of East Galicia in the $20^{\text {th }}$ century prior to the Second World War was the national idea that was reflected through the fact that the repertoires were dominated by works created by Ukrainian composers. Such policy with regard to repertoires confirmed the nationally-oriented setting of musical enlightenment that was contributing to the growth and development of the national culture; national self-actualisation of Ukrainians; shaping of a creative personality able to unite; bringing the nation closer to harmony and preserving its identity as it was facing challenges such as loss of statehood or statelessness. It contributed to the enhancement of amateur musical practice, to the emergence of numerous musical and singing bands that were organising concerts of secular and religious music on a decent level, satisfying the needs of Ukrainians. These factors let us assume that musical enlightenment was a natural process that was defined, on the one hand, by "ripening" of internal aesthetic needs of Ukrainians and emergence of creative force in the homeland that were putting effort into improving the cultural level of the indigenous population; and on the other hand, by national tendencies of the art culture that have specifically manifested themselves in the local conditions as a sort of a response to the policy pursued by the authorities, aimed at Polonisation and Germanisation of the people. Ukrainian efforts in the area of musical enlightenment verified the uniqueness of their musical culture and contributed to the accumulation 
of personal experience that ultimately facilitated its rebirth and further growth and development.

Musical and educational practice in Eastern Galicia of the first third of the $20^{\text {th }}$ century contributed to the development of concert performance verbal forms that was reflected in the spread of such forms among the audience as a musical academy, lecture concert, reviews, competitions, evenings and so on. Systematic work on organization and holding concerts among the wide circles of the Galicians, engaging them to participate actively in creative groups (choirs, theater and orchestral circles) made it possible to successfully implement educational functions and, at the same time, to enhance the overall and cultural level of the Ukrainian population, its national consciousness. Music enlightenment has revealed a very important feature of the Ukrainian community of that time - its ability to self-education.

\section{REFERENCES}

Апраксина, О., 1956, Очерки по истории художественного воспитания. Москва: АПН РСФСР.

Губ'як, В., 2004, Просвітницький рух у Західному Поділлі в контексті украйнського національного культурного відродження (60-і роки XIX - 30-і роки XX cm.). Автореф. Дис. ... канд. Іст. Наук., Київ.

Даль, В., 2000, Толковый словарь русского языка: современная версия. Москва: «Эксмо».

Жорнова, О., 2012, Культуротворчість: Історія терміну та еволюиія поняття. In: Міждисииплінарні дослідження в науиі та освіті. Психологічні науки. Збірник праць Першої Міжнародної науково-методичної конферениії (7 травня 2012 p.), http://www.es.rae.ru/mino/158-1090 [access:19.05.2017].

Звіт дирекиії державного ліцею і гімназії ім. В. Ягелли за рік шкільний 1938/39. In: ЦДІАУ м. Львів, фонд 179, опис 3, р. 344, Дрого́бич.

Кияновська, Л., 2000, Стильова еволюція галицької музичної культури ХIXХХ cm. Тернопіль: «Астон».

Кузнецов, С. (ред.), 2001, Современный толковый словарь русского языка. Санкт-Петербу́рг: Норинт.

Мельник, М., 2009, Театралізований тематичний кониерт як синтетичний жанр сценічних мистецтв. Автореф. Дис. ... канд. Мистецтвознавства, Київ.

Мельник, О., 2009, Формування досвіду музично-просвітницької діяльності майбутніх вчителів музики як педагогічна проблема. «Науковий часопис Національного педагогічного університету імені М.П. Драгоманова», Серія 14, Вип. 8 (13), Київ: НПу. 
Ожегов, С., 1985, Словарь русского языка. Москва: «Русский язык».

Помелова, Е., 2005, Просветительство и его роль в развитии образования. Автореф. Дис. ... канд. пед. наук, Казань.

Промова, виголошена Миколою Міхновським у Харкові 18 березня 1909 р. на святі в честь Тараса Шевченка, 1909. «Рідний край», Ч. 7, Київ.

Рудницький, Л., Фешовець, О. (ред.), 2003, Мислителі німецького романтизму. Івано-Франківськ: Лілея-НВ.

Савельева, Н., 2013, Музыкальное просветительство в деятельности кониертно-филармонических организаиии. Теория, история, практика, Саратов.

Самойленко, О., 2009, Феномен “музичної свідомості” Д. Шостаковича у контексті культури другої половини XX - початку ХХІ століття. «Часопис Національної музичної академії України ім. П.І. Чайковського», № 2 (3), Київ: НМАУ.

Селицкий, А., 2012, Не складьвать оружия! (Освещение работь филармонии в СМИ). In: Музыковедение - океан возможностей. Избранные статьи. Ростов-на-Дону: Ростовская государственная консерватория им. С.В. Рахманинова.

Семчишин, М., 1993, Тисяча років украӥнської культури. Історичний огляд культурного процесу. Київ: «Друга рука».

Ющишин, I., 1927, Про шкільне самоврядування. «Шлях навчання і виховання», Ч. 4.

\title{
WARTOŚCI W EDUKACJI MUZYCZNEJ (NA PRZYKŁADZIE GALICJI WSCHODNIEJ W PIERWSZEJ POŁOWIE XX WIEKU)
}

\begin{abstract}
Abstrakt: Wykształcenie jest zjawiskiem społecznym i kulturowym, a jego obowiązkowym atrybutem jest nie tylko nowa wiedza, ale także jej transfer. Początki edukacji muzycznej są zakorzenione w wiedzy dotyczącej korzystnego wpływu muzyki na ludzką duszę i jej znaczącego efektu edukacyjnego. Wykształcenie muzyczne może być postrzegane jako działalność, która zapewni rozwój zainteresowań muzycznych, potrzeb i gustów oraz generalnie przyczynia się do poznania podstaw muzyki.

Edukacja oparta na wiedzy muzycznej ma również istotny wpływ na osobisty rozwój kultury człowieka. Stanowi edukacyjny pomysł do zapewnienia szerokiego dostępu do prawdziwych wartości muzycznych. Jako działalność edukacja muzyczna jest ściśle związana z problemami wychowania i kształcenia. Jej głównym celem jest wzbudzenie zainteresowania różnych grup muzycznych takimi kategoriami muzyki, jak: pieśni narodowe, ludowe czy inne, wchodzące w zakres światowego dziedzictwa muzycznego. Ważnym zadaniem edukacji muzycznej jest częsty kontakt słuchaczy z artystami. Istotnym czynnikiem w rozwoju kultury ukraińskiej Galicji Wschodniej w pierwszej połowie XX wieku były grupy amatorskie o charakterze edukacyjno-kulturalnym, jak np. „Proswita”, „Bojan”, „Ridna szkola”, „Plast”, „Sich”. Ich
\end{abstract}


członkowie, muzyką swą aktywnie popierali tradycję i ukraińską tożsamość narodową, przyczyniając się tym samym do rozwoju postępu kulturowego. Działalność koncertowa chórów, orkiestr i grup teatralnych tych zrzeszeń stanowiła ważny element w kontynuowaniu tradycji i krzewieniu kultury muzycznej.

Słowa kluczowe: edukacja, edukacja muzyczna, koncert, samokształcenie, Galicja Wschodnia 